\title{
29-“Cangar” ve “Köroğlu” destanları arasındaki epik benzerlikler
}

\section{Lamiya NASÍROVA ${ }^{1}$} APA: Nasirova, L. (2020). “Cangar" ve "Köroğlu” destanlari arasindaki epik benzerlikler.
RumeliDE Dil ve Edebiyat Araştırmalar Dergisi, (Ö8), 368-381. DOI: 10.2900o/rumelide.821858.

\section{$\ddot{\mathbf{O} z}$}

“Köroğlu”" destanı ve Moğol kahramanlık destanlarından olan “Cangar” destanlarının ortaya çıktığ koşullar benzeştiğinden anlatılardaki karakterlerin özellikleri, motif, tema ve içerik, mitolojik hayal gücü ve olağanüstü unsurlar benzer ve ortak özellikler ihtiva etmektedir. Araştırmanın önemli bir yönü Moğol ve Türk halklarının zengin anlatı geleneklerinin incelenmesi ve kahramanların tarihsel mücadelesinin analizidir. Araştırmanın temel yöntemi analiz ve karşılaştırmalı analiz yöntemidir. Özgürlük, hak ve adalet mücadelesi her iki destanın ana temasıdır. Vatanın düşmanlardan korunması ve ülkenin savunulması destan kahramanları için yaşamın gayesi mertebesindedir. Kahramanların özgür bir yaşam için verdikleri mücadele her iki destanın temel motiflerindendir. Moğol destanında Cangar, Al Hongor, Sovar, Mingyan; "Köroğlu” destanında Deli Hasan, Ayvaz gibi kahramanlar yenilmez kahramanlardır. Halk edebiyatının ana öğelerinden biri olan mitlerin efsanelerdeki varlığı, tasvir edilen olaylarda efsanevi öğeler ve büyülü varlıklar, mitolojik dünya görüşünün izlerini yansıtmaktadır. "Cangar" destanında kahramanlar yeraltı dünyasının büyülü varlıkları ve onların efsanevi güçleriyle savaşmıştır. "Köroğlu" destanında da mistik bir dünya görüşünü ifade eden olaylar ve sihirli güçlere sahip karakterler vardır. Kahramanlık betimlemeleriyle zengin olan "Cangar" ve "Köroğlu" destanları halkın gelenek ve göreneklerinin, dünya görüşünün, millî ve manevi değerlerinin bir yansımasıdır.

Anahtar kelimeler: Moğol, Cangar, destan, Köroğlu, karşılaştırma

\section{Epic similarities between "Koroglu" and "Jangar" folktales}

\begin{abstract}
The Mongolian heroic epic of "Jangar" and "Koroglu" have substantial number of common features in terms of their emergence, mythological imaginations and reflections, nature of characters and similar motives in their plots. The essential feature of the research work is studying epic traditions of Mongolian and Turkish nations and analysis of historical struggle of heros. The main method of study is the method of research and comparative analysis. Fighting over freedom and justice are of the essence for both epics. Defending motherland from outlanders has been turned into life ideal for the heros of epics. One of the main motives of both folktales is comprised of heroic struggle of characters over freedom. Jangar, Al Hongor, Sovar, Mingian from Mongolian epic and Koroglu, Dali Hasan, Eivaz from the epic of Koroglu are undefeatable heros portrayed in the epics. Existence of mythological elements in the epics as one of the main directions in folk literature, occasions that bear mythological elements and magic figures confirm the traces of mythological beliefs. Dark forces fight with mythological forces in the "Epic of Jangar" and events involving mythological views, magic creatures are frequently observed in the epic of "Koroglu".
\end{abstract}

Doktora öğrencisi, Azerbaycan Ulusal Bilim Akademisi, Edebiyat Şubesi (Bakü, Azerbaycan), nasiroff11@gmail.com ORCID ID: oooo-0002-3240-9295 [Makale kaylt tarihi: 11.09.2020-kabul tarihi: 20.11.2020; DOI: $10.29000 /$ rumelide. 821858

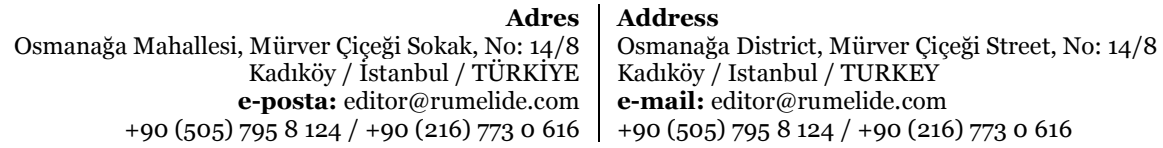


"Jangar" and "Koroglu" tales which are full of heroism scenes are manifestations of nationwide customs, vision and moral virtues.

Keywords: Mongolian, Jangar, epic, Koroglu, comparison

\section{Giriş}

Dünya halklarının destanları arasında kendine has bir yere sahip olan Türk ve Moğol destanları, Türk ve Moğol halklarının ortak değerlerinin karşılaştırmalı bir şekilde incelenmesine olanak sunmaktadır. Destanlar, halkın gelenek ve göreneklerinin, vatanseverliğinin, özgür ve müreffeh bir yaşam mücadelesinin sanatsal bir ifadesidir. "Kahramanlık destanlarının temel özelliği insanların tarihlerinde yer alan kahramanlık sayfalarını oluşturan mücadeleleri aktarmalarıdır. Büyük tarihsel dönemin kahramanları, savaş sahneleri, kılıç sesleri betimlenerek insanlar yeni bir tarihi oluşturur."(Caferli, 2007: 10) Vatanın yabancılardan korunması ve özgürlük mücadelesi her zaman kahramanlık destanlarının ana teması olmuştur.

Altay folklorundaki en önemli ve yaygın tür kahramanlık destanlarıdır. Destan; masal, kahramanlık masalları, kahramanlık şiirleri ve benzeri şekillerde de adlandırılır (Altay Destanları ve Efsaneleri, 2016: 5) Batı Moğolların yani Kalmık halkının mücadelelerle dolu tarihini ve kahramanlarını anlatan "Cangar" destanı aynı zamanda halkın gelenek ve göreneklerinin, dünya görüşünün, millî ve manevi değerlerinin bir yansımasıdır. "Cangar efsanesi` Moğol halkının kahramanlığını, barış ve yurtseverliğini yansitıyor". (“Cangar” 2017: 2) "Cangar" destanı Babek Gurbanov tarafından dilimize çevrilmiş ve 2017 senesinde yayınlanmıştır. Bu çeviri, Azerbaycan ve Moğol destanlarının karşılaştırmalı analizi için paha biçilemez bir kaynaktır.

Destanın kökeni XIII veya XVI yüzyllara dayanmaktadır. Destana ait ilk bilimsel çalışma on dokuzuncu yüzyılın başlarında yapılmıştır. Destanın efsane ve türkü olarak adlandırılan kahramanlık bölümlerinden biri, çevirmen-etnolog Benjamin Bergman tarafından yayınlanmıştır. Destanda İslam öncesi mitolojik kahramanların yanı sıra Şamanizm ve Budizm unsurları, arkaik döneme ait izler, destanın antik döneme ait olduğunu kanıtlamaktadır. Destanın günümüze kadar korunarak ulaşmasında destan okuyucularının ve savaşçıların kahramanlıklarının yadsınamaz bir rolü olduğu aşikardır. "Altay halkının kalbinde iki gelenek mevcuttur: biri Şamanizm, diğeri ise Altayca'da `Kayçiler` adı verilen okuyucular (masalcılar) veya destan anlatıcılarıdır (Altay Destanları ve Efsaneleri 2016: 268) Destanın müziğini yapan ve mükemmel hatıralara sahip olan destancılar (cangarcılar), Kalmık halkının gelenek ve göreneklerini sanatları aracılığı ile nesilden nesile aktarmışlardır.

Kalmık halkının tarihsel mücadelelesinin başarıya ulaşmasında kahraman komutan Esen Han'ın büyük emekleri vardır. "Bu tarihsel aşama, Kalmık halkının millî uyanışında, millî bilincinin güçlendirilmesinde ve geliştirilmesinde çok önemli bir etkendir.” (Gurbanov 2017: 2) Bu tarihsel nedenlerden doğan mücadele ruhu ile ülkenin savunması Kalmık halkı için yaşamın ideali haline gelmiştir. Tanınmış edebiyat eleştirmeni ve akademisyen Victor Jirmunski, "Cangar" destanındaki kahramanların mücadelesinin tarihsel olaylarla örtüştüğünü ve kahramanların tarihi şahısların yansıması olduğunu ortaya çıkarmıştır. Kırgızlar ve Kalmıklar arasındaki tarihi mücadelede destandaki savaşçı Konurbay, "Cangar" destanının ana kahramanlarından biri olan Hongor'u yansıtmaktadır (Meletinsiy $1963: 374$ )

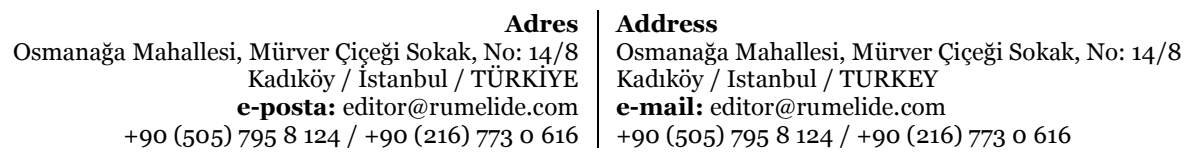


Kalmık halkının kültürel gelişimi pek çok halktan etkilenmesi sayesinde gerçekleşmiştir. Araştırmacılara göre Kalmıklar, Moğol, Tibet ve Hint kültürlerinin etkisinden de yararlanarak başta folklor olmak üzere maddi ve manevi açıdan zenginleşmişlerdir. "Cangar" destanında sosyal ve kültürel yaşamla ilgili çok sayıda Türkçe kelimenin kullanımı, "gururlu Türk sultanı" ifadesinin yer alması Türk halklarının Kalmık halkı üzerindeki etkisi olarak değerlendirilmelidir.

Kahramanlık sahneleri açısından zengin olan "Cangar" destanı, giriş ve türkü olarak adlandırılan on iki bölümden oluşur. Destanlara özgü şiir ve düzyazı dizisi de bu destanda yer almaktadır. Kahramanların özgür bir yaşam için verdiği mücadele, destanın tüm bölümlerini birleştiren ana temadır. Destanın giriş bölümünde adaletle ve bilgelikle yönetilen Bumba halkının, ideal bir şekilde tasvir edilen ayrımcllı ve adaletsizlikten uzak, mutlu, kaygısız, zengin ve müreffeh bir hayat sürdükleri anlatılmaktadur. İnsanlar her zaman canlı, mutlu, iyimser ve umutludur. Ütopik bir devlet yapısını anlatan destanda, kudretli halk ve dünyaya gelen yeni kahramanlar barış ve huzur içinde, gerçek hayatın kötülüklerinden uzak yaşamaktadırlar:

"Kırk hanlı̆̆ı olan bu ülke

Müstahkem kaleleri ile ünlüydü.

Yirmi beş yll sonra

Orada yllar geçmedi.

Ölüm oraya yaklaşamadı.

İnsanlar dondurucu soğukların ne olduğunu,

Yazın ölümcül sıcağının ne olduğunu

Bilmiyorlardı" (Cangar 2017: 19)

Ütopik Bumba ülkesi adil bir hükümdar, halkın koruyucusu Cangar tarafından ahlaki saflıkla ve herkese eşit davranarak yönetiliyordu. O, 6012 kahramanla birlikte vatanını düşmanların saldırılarından koruyor ve tüm zorlukların üstesinden gelebiliyordu. "Bumba'nın savaş̧̧larının her biri onu destansı bir kahraman yapan ve silah arkadaşlarından ayıran farklı bir özelliğe sahiptir. Cesur, akıllı olan savaşçlar ve Cangar millî karakterin en iyi niteliklerinin ve özelliklerinin somutlaşmış halidir çünkü onların sahip oldukları özellikler insan dehasının ürünüdür” (Cangar ve Cangarşinaslık 2001: 5)

Moğol destanındaki ideal bir toplum ve adil bir hükümdar teması, Azerbaycan edebiyatının en önemli şairlerinden biri olan Nizami Gencevî’nin (Genceli Nizamî) "İskendernâme”sinde de ana temadır. Şairin en muhteşem eserlerinden biri olan "İskendernâme" eserindeki "İskender'in Kuzeye Ulaşması ve Yecüc Kapısını Kapatması" (İskendernâme 2004: 585] bölümünde ideal toplumun tasviri, adaletle yönetilen ülke ve yaşlı bilgelerin fikirleriyle yönetilen ideal toplum ve adaletin hakim olduğu ülke anlatılır ki bu anlatım da Moğol destanındaki fikirlerle örtüşmektedir. Bu ülkedeki insanlar yolsuzluk, kötülük ve haramdan uzak, eşit haklara ve ortak ideallere sahip olarak yaşamaktadırlar:

"Herkes aynı servete sahip,

Tüm malları eşit olarak bölüyoruz.

Artık kimsemiz yok,

Ağladığımızda kimse gülmez" (İskendernâme 2004: 589)

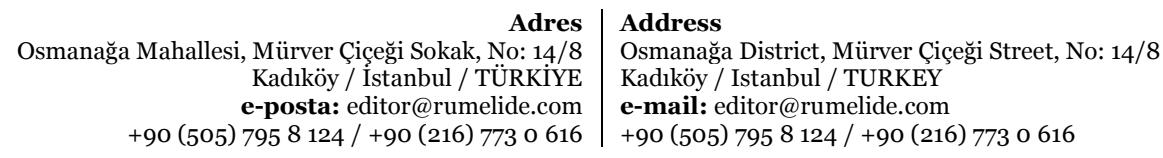


Moğol destanı ve "Köroğlu" destanı tarih, tema ve fikir, ortak motifler, kahramanlar ve mitolojik dünya görüşünün yansıması açısından yakından ilişkilidir. Türk destanları arasında özel bir yeri olan vatanseverlik, mücadele, kahramanlık gibi kutsal özellikleri öne çıkaran "Köroğlu” destanı halkın zengin tarihi geçmişinin sanatsal olarak ifade edildiği folklor ürünlerinden biridir. "Köroğlu" destanı genel olarak bir dereceye kadar çeşitli Türk (ve bazı Türk olmayan) halklara yayılmış olsa da, mükemmel bir şiirsel eser olarak tarihsel bakımdan Azerbaycan halkına - Azerbaycan Türklerine aittir (Caferov 1998: 125) XVII-XVIII yüzyllarda ortaya çıkan "Köroğlu" destanı tarihsel olayları yansıtmaktadır. Bilimsel araştırmalar destanın birçok nüshasının çok eski olduğunu ortaya koymuştur. "Köroğlu" efsanesi Göktürk Hakanlığı dönemi, Orta Asya'da Arap baskısına karşı ayaklanmış ve Azerbaycan'da daha çok yaygınlaşmış Babek ayaklanması ve Osmanlı-Safevi savaşları gibi tarihi olayların izlerini taşımaktadır (Bayat 2009: 35)

On dokuzuncu yüzyılın başlarında destanın kapsamlı bilimsel araştırmasına başlanmış ve destanın mevcut olan çeşitli versiyonları yayınlanmıştır. "Köroğlu" destanının ana bölümü ve daha sonra toplanan çeşitli bölümleri farklı kopyalarda basıldığından ana çizgisi bir dereceye kadar korunmuştur. Araştırmada destanın temel nüshası ve Paris nüshaları esas alınmış, Moğol destanı ile paralellikleri karşılaş̧ırılmıştır.

Destanın ana versiyonu, yirmiden fazla kahramanlık anlatısı ile motif ve içerik açısından çok zengin olan kollardan oluşur. Köroğlu'nun Rûm (Anadolu), Erzurum, İstanbul, Türkmen ve Derbent'e yaptığı seferleri ayrı ayrı bölümlerde anlatılmış, kahramanların cesaretleri ve yiğitlikleri eseri süslemiştir. "Köroğlu" destanındaki her bölüm "kol" adını almaktadır ki kolların ana teması; vatanın savunulması, kahramanın yurduna ve en değerli varlıklarına el koyan beylere, paşalara ve sultanlara karşı savaşmasıdır. Mücadele ve cengaverlik motifleri açısından zengin olan destan, tarihsel olayları ele almaktadır.. Türkiye'de 16. ve 17. yüzyılın sonlarında başlayarak Azerbaycan'a yayılan büyük bir halk ayaklanması olarak bilinen Celali İsyanı, teması, motifleri ve içeriğiyle birlikte "Köroğlu" destanına yansımıştır. Köroğlu'nun, aslında bir Celili eşkiyası olması; Özdemiroğlu Osman Paşa ordusuna ise bir dehaletle katılmış bulunması çok muhtemeldir” (Banarlı 1998: 630)

"Cangar" ve "Köroğlu" destanlarının ana fikri vatanın savunulması ve düşmana karşı yapılan savaşlardır. Bu destanların kahramanlarının hayattaki tek amacı adaletsizlikle savaşmak ve ülkelerini dış güçlerden muhafaza etmektir. Kahramanların özgürce yaşamak için bitmek tükenmek bilmeyen kahramanca mücadelesi, her iki destanın temelinde yer alır."Türk destan geleneğinde, kahramanların gençlik döneminden yaşlılık dönemine geçişi anlatılır. Bu tüm destanlarda bir veya birkaç dereceye kadar görülür. Çünkü insanların zihninde kahramanlık hiçbir zaman sona ermez, yani hiçbir aşamada sonu yoktur. "Manas", "Corabatır", "Cangar", "Köroğlu" ve diğer destanlarımız bu durumun örneklendirilmesi açısından önem arz eder.” (Eposşinaslık: Problemler, Mülahazalar, 2013: 11)

\section{2. "Cangar" ve "Köroğlu” destanlarında kahramanların tarihi mücadelesi}

"Cangar" destanında esas kahramanı ütopik Bumba ülkesinin adaletli hükümdarı Cangar'dır, o, anlatı boyunca 6012 kahramanla birlikte hem şulmuslarla hem de yeraltında yaşayan büyülü güçlere sahip canavarlarla savaşır. Şulmuslar destan kahramanlarının mücadele ettiği düşmanlarıdır. (Buyar 2016: 126) Destanda bu düşmanlara genel olarak kara güçler, devler, mangas veya canavarlar denir. “Canavar adamları yiyen yaratık Budizm öncesi Şamanizm’in panteonuna aittir. 'Cangar`ın çok eski zamanlarda ortaya çıkan kollarında (şiirlerinde) kahramanların Mangaslar’la savaştığı anlatılırken

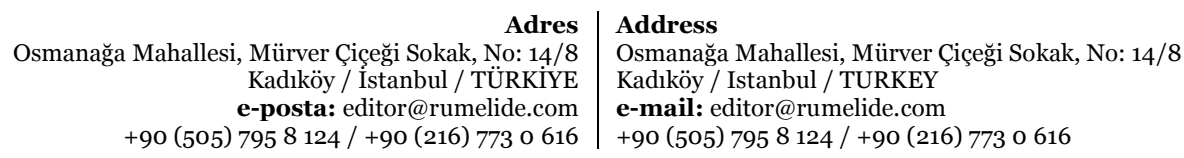


daha sonra, yani 15. yüzyılın ortalarında tek bir destan olarak birleştirildiğinde, Kalmıklar’n tüm düşmanları (koyrotlar) Mangas olarak adlandırmaya başlanmıştır.” (Cangar 2017: 99)

Destanın farklı yerlerinde Mengen Şikşirgi, Zarin Zan Tayşa, Şara Kuyurgun, Alya Monhlya, Dogşon Mangna Han gibi kahramanlar canavar düşmanlara karşı savaşırlar. Destanda kahramanların gücü Maha-Kala gibi korkunç tanrıların gücüne eşittir. Moğol masallarında kahramanlar yenilmezlikleri ile bilinirler. Bu destandaki yenilmez kahramanlar Al Hongor, Sovar, Mingyan gibi isimlerdir.. 6012 kahramanı sol taraftan Al Hongor ve sağ taraftan rahip Altan Tsedji komuta eder. Bumba ülkesinin savaşçlları yorulmak bilmezler. Kahramanlar mücadeleden, savaşmaktan ve şöhret kazanmaktan asla yorulmazlar:

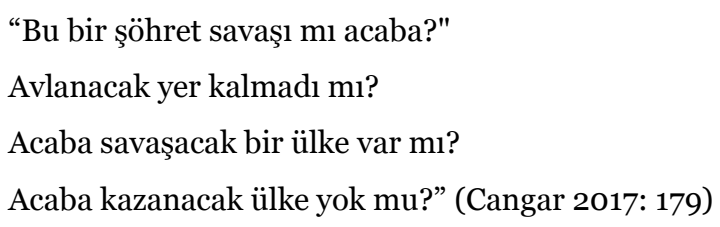

Ütopik Bumba ülkesinin kahramanları neden olmadan savaşmazlar, onlar barış taraftarıdır. Bu çatışmaların nedenleri arasında düşmanların kahramanı esir etmesi veya öldürmek istemesi, kahramanların atlarının kaçırılması, düşmanın kahramanın en değerli varlıkları olan atını ve eşini ele geçirme arzusu vs. sıralanabilir.

Destan kahramanlarının canavarlarla mücadelesinde elde ettiği zaferler her zaman iyiliğin kötülük üzerindeki zaferi olarak anlatılır. İyiyi temsil eden kahramanlar, kötü güçlerin bir arada bulunduğu çöllerde zorlumücadelelere girişirler. Destanda, iyilik ve kötülük mücadelesi aydınlık dünyanın zaferi, iyilik olarak yüceltilir ve "Avesta" motifleri kendini gösterir. Bu eski tasavvurlar, fikirler "Avesta" kitabında anlatılan hayırsever, şefkatli tanrılardan olan Hürmüz ve en yakın yardımcısı Zerdüştile kötülük, mutsuzluk ve nefret ise Ehrimar ile bütünleştirilerekilmi, dini, felsefi açıdan tümüyle hayırlaşerrin ebedi savaşı konseptine yükseltilmiştir.”(Alibeyzade 2005: 93) Destanın on birinci bölümünde, Cangar’ın düşmanlara karşı gerçekleştirdiği ölüm kalım savaşları sonrasında kazandığı zaferler, bu sonsuz mücadelenin sadece bir örneğidir.(Cangar 2017: 248)

"Köroğlu" destanı, halkın tarihsel geçmişinin izlerini taşıyan, yaşam tarzı ve geçimi ile yakından bağlantılı motifler açısından zengin bir folklor örneğidir. Efsanenin gerçek kahramanı olan Köroğlu'nun asıl adı Rövşen'dir. Köroğlu Çamlıbel'e yerleşmiş ve 7777 delisiyle hak ve adalet yolunda savaşır. Köroğlu hem tarihi bir figür hem de millî bir kahramandır. Efsanede isyancı (Celali) olan Köroğlu bir yandan aşık gibi türküler okurken, diğer yandan dadelilerin şanını, kahramanlığını öven şiirler söyler. Köroğlu'nun kimliği ile ilgili bilgi veren ilk kaynaklardan biri Evliya Çelebi`dir, o, Köroğlu'nu, Anadolu'nun Kuzeybatı bölgesinde kaçak yaşayan ünlü bir haydut olarak anlatmıştır. (Çelebi 2010: 14) Köroğlu ve diğer kahramanların tarihiliği destandaki birçok karakterin isimlerinin gerçek olmasıyla da kendisini gösterir. Kara Yazıcı Deli Hasan (1599-1603), Arnavut Kizir Mustafa, Köse Sefer (1599), Köroğlu ve diğerleri. Anlatıda kahramanların başarılı mücadeleleri sonrasında şan ve şöhretleri komşu ülkelerde yankılanıyordu. Hanlara ve paşalara karşı savaşan Köroğlu, mazlumların umudu olmuştu. "Bu anlamda Köroğlu, halkın umutlarını ve isteklerini yücelterek seçkinlere karşı savaşmıştır” (Bayat 2009:11) Köroğlu'nun kahramanları da onunla aynı hedefleri paylaşmış cesaretleri, hünerleri ve kahramanlıklarıyla ünlenmiştir. Deli Hasan, Ayvaz, Demircioğlu gibi deliler cesur, sözünden dönmeyen mert yiğitlerdir. Delilerin meslekleri okçuluk, ata binme, kılıç kullanma ve mızrak atmaktır. Köroğlu ve delileri Hasan Paşa, Arap Reyhan, Bolu Beyi gibi paşalara ve beylere karşı

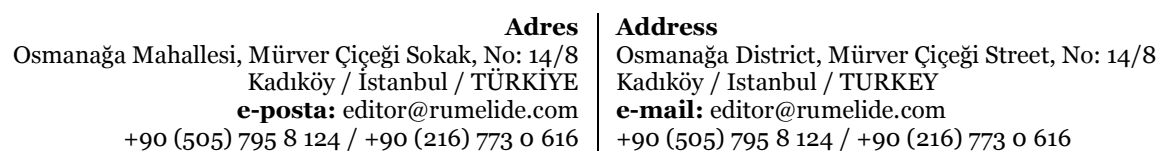


savaşmıştır. destanda cömert ve cesur Köroğlu'na beyler ve paşalar “deli” der. Köroğlu ve delilerinin yaşadığı Çamlıbel, kahramanın Mısri kılıcı ve Kırat destanın ana unsurlarındandır. Köroğlu Kırat adını verdiği atı ile birlikte seferlere çlkar, hedefine ulaşmak için cesurca savaşır.

"Cangar" destanında olduğu gibi, Türk destanları da kahramanların adını taşıyan ayrı kollar ve hikayelerden oluşur. Bu bölümlerin içeriğindeki ortak fikir hakadalet uğruna verilen savaş ve cesaret motifleridir.

"Cangar" ve "Köroğlu" destanlarında, kahramanlar küçük yaşlarından itibaren yiğitlik göstermeye ve düşmanlarla mücadele etmeye başlamaktadır. Moğol destanında mistik hayal gücünün izleri, kahramanların düşmanlara karşı mücadelesinde kendini göstermektedir. "Moğol destanında ilk savaşına giden kahramanların yaşı da bir masalı andırmaktadır. Cangar, Altan-Secin'in atını kaçırmayı altı yaşında gerçekleştirmiş ve bu olay destanda ayrı bir bölüm halinde işlenmiştir. Bu kahramanlıkta Cangar'ın gelecekteki baş kahramanı olan beş yaşındaki arkadaşı Hongor ona yardımcı oluyor"(Jirmunski 2017: 21) Çocukluk yaşından itibaren cesaret göstermek, kaleler almak, soylular ve hanlarla savaşmak sıradan bir olay halini almıştır. Ana kahraman Cangar Bogdo, yedi yaşına kadar birçok kahramanlık göstermiştir. (Cangar 2017: 17-18) Üç yaşında yetim kaldığında düşmana karşı savaşmış, üç düşman kalesini yok etmiş ve beş yaşına geldiğinde beş hükümdarı esir etmeyi başarmıştır. Yedi yaşına geldiği zaman ise yedi ülkenin hanı olmuş, "büyük ve şanlı Cangar" adını almıştır. Destanın bir başka kahramanı Al Hongor da çocukluğundan itibaren kahramanlıklara imza atan biridir. Beş yaşında Cangar'la kahin Altan Tsedji’nin atını kaçırma başarısını göstermiştir.

"Köroğlu" destanında Ayvaz on üç-on dört yaşlarınnda bir genç olarak anlatılmıştır. Köroğlu'nun oğlu olarak kabul ettiği Ayvaz yakışıklılığı, cesareti ve yiğitliği ile delilerin gerisinde kalmazdı. Köroğlu, Kars seferi sırasında bir taş kilisede saklandığında, Ayvaz delileri toplayıp silahlandıktan sonra onun peşinden gider. Cesurca Arap Reyhan ile savaşır ve onu savaşta yener. Köroğlu Ayvaz’ı övdüğu türküsünde şöyle der:

"Oğlan, tara seslen

Yardımcınız olsun Alı

Köroğlu der Ayvaz Balı,

Çal, kilııın keskin olsun” (Köroğlu. Paris Baskısı 2005: 127)

"Cangar" destanındaki kahramanların gücü ve kuvveti de mitolojik özellikler taşımaktadır. Kahramanların sihirli ve olağanüstü güçleri vardır. Onlar zor zamanlarında yüzlerini değiştirir ve böylece düşmanı yener.. Destanın "Al Aslan Ulan Hongor'un nasıl evlenmesi” başlıklı bölümünde Hongor, kendisinin ve atının görünüşünü değiştirir. (Cangar 2017: 39) Kahramanların bu yeteneği, destanın bazı bölümlerinde hile olarak yorumlanır. Hongor hile ile kirli ve bitlerden muzdarip bir çocuğu, atı Otsola Kekeni'yi de iki yaşında zayıflıktan ölecek dereceye gelmiş bir ata çevirir. Destanın yedinci bölümünde Koşun Ulan, Kara Çlgan, Alya Şonhor adlı üç çocuk savaşa giden kahramana karşı aynı hileyi kullanırlar (Cangar 2017: 179) Destanın on birinci bölümünde, düşman Şara Kuyurgu'nun birlikleri Cangar’ın sarayını kuşattığında, Hongor sarayı olağanüstü gücüyle savunur:

"O zaman, kirişe sığabilecek kadar süratle giden

Okları topladı, bir kerede bıraktı ve aynı anda seksen bin adamı yere serdi.

Bir seferde yüzlerce düşmanın başlarını bedenlerinden ayırdılar” (Cangar 2017: 283].

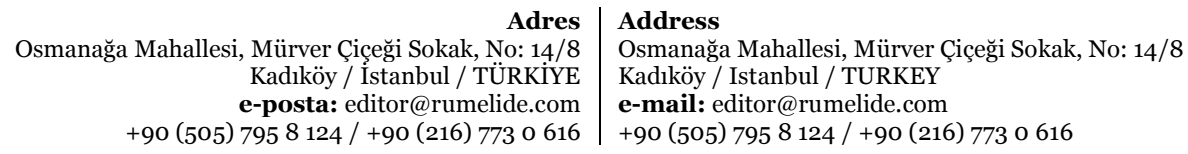


Her iki destanda da geleneksel olarak, kahramanların gücünün abartılı bir şekilde tanımlandığı görülür. "Köroğlu" destanında, kahramanların cesareti, kahramanlığı ve gücü şiirlerde dile getirilir.

“... Mısır, İstanbul, Şam,

Önündeki tek koç Köroğlu'dur" (Köroğlu 200: 89)

Destanda Köroğlu'nun mücadelesi ve takdire şayan cesareti anlatılmıştır. "Köroğlu'nun karakteristik özellikleri, özellikle de cesareti ve mücadelesi, çok sayıda mübalağalar aracilı̆̆yla ustalıkla işlenmiştir.” (Azizhan, 2015: 240) Destanın “Köroğlu’nun Erzurum Ziyareti” bölümünde Demircioğlu Kara pehlivanın meydandaki mertliği ve cesareti şöyle anlatılıre:

"Meydanda yürüyen bir aslanım ben,

Hışm ile düşmanın bağrını ezen,

Tülek terlen gibi havada uçan,

Sonra yakalanırsın, yiğit!” (Köroğlu 2005: 119)

Moğol destanında savaşçıların kahramanlık içgüdüsü nesilden nesile aktarılır. Cangar, oğlu Şovsura’yı nasihat ederken şunları diyor: "Oğul babadan gelir, böylece vatana güvenle destek çıabilir. Oğlum, Bumba'nın sana ihtiyacı olduğunu unutma”. (Cangar 2017: 296) Şovşur üç yaşındayken düşman ordusuna saldırır ve soylularla savaşır. Destanın yedinci bölümünde, Koşun Ulan, Kara Cllgan, Alya Şonhor adlı üç çocuğun anlatılmasıyla yine Kalmık halkının mücadelesinin önemli bir yönüne ışı tutulmaktadır. (Cangar 2017: 179) Bumba'da korkusuzca, cesaret ve öğütlerle büyüyen çocukların esas gayesivatanseverlik duygusunu korumaktır. Üç cesur çocuk, Badmin Ulan gibi yenilmez bir savaşçı ile savaşmak için gönüllü olarak yola çıkar. Onlar, büyük savaşçı rahip Altan Tsedji’nin tavsiyesine uyarak tüm engellerin üstesinden gelirler ve Cangar’n düşmanı Badmin Ulan ile savaştan zaferle dönerler.

Destan kahramanlarının hanlarla mücadelesini yansıtan bölümlerinden bir diğeri ise "Yaşlı (Koca) Bahadır Sanal'ın Cesareti” adını alır. (Cangar 2017: 104) Tüm dünyanın hükümdarı olan Cangar, büyük savaşçı Sanal Bahadırı düşmanı Zarin Zan Tayşa'nın yanına gönderir. Huzurlu bir ülkenin hükümdarı Cangar, düşmanlara karşı mücadelede barış taraftarıdır. Hongor'u, Zarin Zan Tayşa'nın yanına gönderirken, adil hükümdar şöyle der:

"Barış istiyorsanız, barışa itaat edin,

Savaş istiyorsa, savaşı kabul et!" (Cangar 2017: 105)

Destanın “Al Aslan Ulan Hongor Nasıl Evlenir?” adlı diğer bölümünde Hongor, rakibi olan savaşçıya adil davranır. Al Hongor mücadele ettiği savaşçıya son isteğini sorar:

"Savaşta kaybeden taraf,

Son dileğini ifade edebilir.

Şimdi ne istiyorsun?” (Cangar 2017: 65)

Yiğidin mertliğine karşı adil davranma motifi “Köroğlu” destanında da görülmektedir. Köroğlu aman dileyene el kaldırmaz, cesurca savaşan düşmanını affeder. Bürcü Sultan ile savaşı kazanmasına rağmen, onun adına üzülür. Destanın “Köroğlu ile Deli Hasan” bölümünde Deli Hasan'ın korkusuzluğu ve cesaretini görenKöroğlu onu affederek kılıcının altından geçirir vearkadaşı,kardeşi olarak kabul eder. (Köroğlu 2005: 63) 
"Cangar" destanında, kahramanın atının kaçırılması, düşmanla savaşmak için yeterli bir nedendir. Destanın, "Duktahul'un Torunu Duuçin’in Oğlu Alya Monhlya `nın, Büyük Noyan Cangar’ın On Sekiz Bin Açık Sarı Cins Atlarını Kaçırması” bölümünde (Cangar 2017: 136) Cangar atlarının kaçırılmasını kendisine yapılmış hakaret addeder.. Bu sebepledüşmanlarla savaşmamayı korkaklık olarak görür. Atının kaçırılması bir savaşçı için utançvericidir, şan ve şöhretini lekeleyici bir olaydır. Kahraman bazen yalnız, gerektiğinde ise diğer kahramanlarla birlikte savaşa katılır. Destanın bu bölümünde Cangar, atlarını geri almak için yiğidi Hongor ve savaşçıları ile beraber yola çıkar. Kırk dokuz günlük mücadeleden sonra on sekiz bin atla geri dönerler.

“Köroğlu” destanında "Hamza'nın Kırat'ı Alması" (Köroğlu 2005: 165) bölümü bu anlamda Moğol destanı ile örtüşmektedir. Koç Köroğlu'nun gücüne güç katan ve onu daha da cesur kılan Kırat azametiyle hanları ve paşaları korkutur. Tokatlı Mahmud Paşa, Kırat’ı kendisine getirecek olanabir çok vaatte bulunur. Köroğlu, Kel Hamza tarafından kaçırılan atını geri getirmek için savaşmak üzere Tokat'a gider. Mahmud Paşa'nın ordusuyla savaşan Köroğlu, Kırat'ına binerek Çamlıbel'e döner.

Moğol destanı ve "Köroğlu" destanı kahramanlık, cesaret ve yiğitlik motifleri bakımından zengindir. "Cangar” destanında Cangar ve 6012 kahramanının mücadelesi, Türk destanı Köroğlu'nda 7777 delisinin verdiği savaşlar oldukça benzerdir.

\section{3. "Cangar" ve "Köroğlu” destanlarında mitolojik motifler}

Kahramanlık destanları, halkların tarihi geçmişini yansıtmanın yanı sıra eski mitolojik tasavvurları da içeriside barındıran zengin edebi ve tarihi kaynaklardır. Moğol ve Türk halklarının mitolojik kahramanlarının kendine özgü nitelikleri olmakla birlikte, iki destan arasında bu açıdan çeşitli benzerlikler de mevcuttur.

Moğol folklorunun en zengin örneklerinden olan kahramanlık destanları, geleneksel olarak mitolojik ve büyülü güçleri içeren olayları ve hikayeleri barındırır. Araştırmaya konu olan "Cangar" destanında birçok mitolojik karakter ve motif bulunmaktadır. Destanda, kahramanlar uzun süre "yedi kez yedi ila kırk dokuz gün" uyuyabilmektedirler. (Cangar 2017: 72) ve bir gün içinde bir aylık mesafeyi kat edebilmektedirler. Periler, devasa devler, kara bulutlar, sarı kanatlı arılar, kötü güçler-şeytanlar, insanların arzularını ve isteklerini yerine getiren Çindamani tılsımı mitolojik bir dünya görüşünün izlerini taşımaktadır. Moğol mitolojisindeki efsanevi yaratıklar "Cangar” destanında kahramanın savaştığı canavarlardır. Destan kahramanlarının yeraltı dünyasında yaşayan canavarlarla mücadelesi, “Şulmusların Gaddar Hanı Şara Gyurgu'nun (Gürgün) Mağlup Edilmesi” bölümünde anlatılmaktadır. (Cangar 2017: 248) Moğol mitolojisinde canavarlar, sadece yeryüzünde değil, aynı zamanda yer altı dünyasında yaşayan şeytani yaratıklardır. Destanın sözü edilen bölümünü diğer bölümlerinden ayıran ana özelliŭi, burada kahramanların mistik ve öteki dünyanın kötü güçlerine karşı savaş vermesidir. Folklor türleri arasında destanlar mitolojik unsurlar içermesi açısından daha fazla dikkat çeker , genel anlamda mitolojik unsurların kahramanlık destanlarına yansıması sıklıkla görülür.

C.Beydili’nin belirttiği gibi, "kültürel kahramanlarla ilgili efsaneler, daha sonra büyülü ve sıradışı nesnelerle öbür dünyaya giden kahramanların başına gelenleri anlatan büyülü masalların oluşumunda rol oynamıştır”. (Beydili 2007: 50) Moğol mitolojisine ait yeraltı dünyasının tasviri ve mistik güçlerin varlığı destandaki kahramanların mücadelesine yansır. Destanın mistik kaynaklara dayanan mitoloji ile yakın bağlantısı, destanın sözü edilen bölümünde, kahramanların savaştığı düşmanların karakterlerine ve mevcut olaylara yansır.

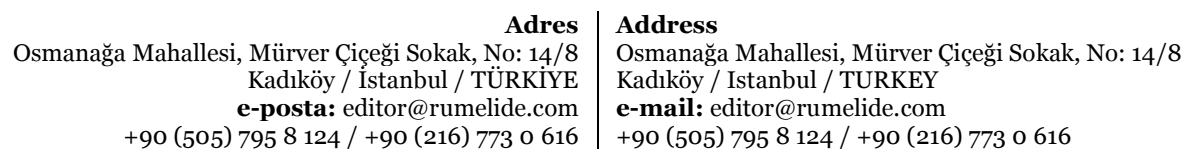


“Cangar” destanında mitolojik dünya görüşünün izleri efsanevi hayal gücüyle yaratılan düşmanlarla kahramanların savaşlarında görülebilir. Kahramanların yeraltı dünyasında, cehennemin yedinci katında karşılaştı̆̆ sihirli ve doğaüstü canavarlar, üç aylık bebek, cadı ve büyülü şseytanlardır. Destanın onbirinci bölümünde (Cangar 2017: 248] yeraltı dünyasının hükümdarı tarafından esir alınan Hongor cehennem ateşinde akılalmaz bir şekilde acı çeker. Her gün kızgın, deri kamçıla bedeni on bir bin kez şaklatılır. Bu cehennemin işkencelerine katlanan Hongor noyanı, hakanı Cangar tarafından kurtarılır. Cesur kahramanı Hongor'u cehennemin yedinci katından kurtarmaya giden Cangar bir cadıyla karşılaşır. Büyücü tarafından birkaç kez aldatılınca büyücüyü kılıcıyla yok eder: "O anda Bogdo, cadının karnını kılıcıyla ikiye böler. Üst kısmı bir ok gibi gökyüzüne, alt kısmı ise dünyanın derinliklerine gider.”(Cangar 2017: 313) Yaşlı kadın (cadı) yeniden belirir, Noyan cadıyı ve çevresindeki yedi genci tekrar öldürür. Dünyanın en derin katmanlarında Cangar şulmuslarla savaşmaya devam eder. Cehennemin karanlık katmanlarında yaşayan beşikteki üç aylık bir bebek aniden Cangar'a saldırır. (Cangar 2017: 314) Bebek intikam almak için kahramanla savaşır. Cangar, olağanüstü güce sahip bu çocukla iki hafta dinlenmeden savaşır, sonunda onu yener ve öldürür. Cangar olağanüstü yeteneklerini yer altı canavarlarıyla savaşmak için kullanır. Burhanlardan yardım isteyerek kara büyü yağmuru yağdırır ve çocuğun susuzluğunu gidermek için büyük bir deniz yaratır. Kahramanların mücadelede adil olma anlayışı cehennem ülkesinde de devam eder. Yalan bir haberle Hongor'un öldüğünü bildiren iki kötü niyetli çocuğu cezalandırmak isteyen Cangar, Hongor’un isteği üzerine onları affeder ve onları öldürmekten vazgeçer. Her türlü eziyetlere gögüs geren kahramanlar cehennemin tüm katlarından geçerek sonunda yeryüzüne varırlar.

"Cangar" destanında kuğular, kahramanın dudaklarına yaşam tohumları serpen canlılar olarak tasvir edilmiştir. Cangar'ın nişanlısı Gerenzal'ın da büyülü güçleri vardır:

“Aniden bir kuğuya dönüşen Gerenzal

Çöl üzerinde bir daire çizdi

En önde uçmaya başladı ”. (Cangar 2017: 101)

Moğol destanında bahsedilen motif "Köroğlu" destanındaki büyülü unsurlarla benzeşmektedir. "Köroğlu” destanındaki "Perizad Hanım'ın Çamlıbel'e Gelişi” ve "Köroğlu ile Beyler” bölümünde büyülü, mucizevi, tılsımlı unsurlar vardır. Cafer Paşa'nın kızı Perizad Hanım büyücülük okulunda okumuş ve bu sanata hakim olmuştur. Büyülü güçleri olan Perizad kaplana, tavşana, yllana dönüşebilir ve kanatlarını kuş gibi çırpabilir. İsm-i Azam duasını okuyarak ve çevresindeki vahşi hayvanları bir araya getirerek Ağcakuz'u şaşırtır. Nişanlısı Ağcakuz’u denemek için bedenini değiştirir ve üstünlüğünü kanıtlar. Perizad Hanım tılsımı ve sihrinin gücüyle Köroğlu ve delilerini zor durumlara sokar. Onların önünde bir büyü yaparak yılana dönüşür, ancak Köroğlu onu insan suretinde görür. Destanın "Köroğlu ile Beyler" kolunda Halil Paşa’nın kızı Dinmaz Hanım cadının büyüsünü bildiğinden büyü ile Köroğlu'nun ellerini ve kollarını bağlar. Dinmaz, Köroğlu'nun Beyleri, kendisini deli yapmak isteğinin farkına varınca bir tılsımlı sözle Köroğlu'nu Halil Paşa için hapseder. Destanların her ikisinde tılsım, suret değiştirme, sihir ve cadı motifleri görüldür, bu da destanlar arasındaki benzerlerliklerden sadece biridir. .

"Köroğlu” destanında Mısri kılıç ve Goşabulag (veya Köpüklü Pınar) efsanevi imgelerin izlerini taşıyan nesnelerdir. Çamlıbel topraklarında, dağların koynunda bulunan Goşabulag’ı mistik özellikleri ve insanlar üzerinde mucizevi etkileri vardır. Destanda pınarın olağandışılığının açıklanması da efsanevi gücüyleyorumlanır. Pınarın büyüklüğü ve köpüklü suyun faydaları destandaki karakterlerin dilinden ifade edilir. Destanın "Alı Kişı” kolunda Hasan Paşa tarafından gözleri kör edilen Alı dünyanın ışığına

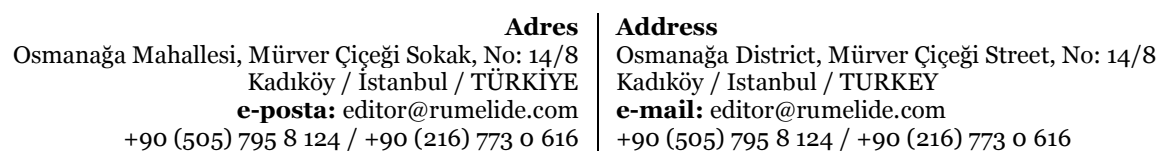


hasret kalır. (Köroğlu 2005: 49) Onun dünyayı görebilmesinin tek ilacı Goşabulag'dadır. Bu nedenle oğlu Rovşan'ı bu mucizevî suyu aramaya gönderir. Dağların eteklerinde yer alan bu çift pınarın pırıl pırıl suyu, Ali'nin gözlerinin ilacıdır. Goşabulag'ın suyu, ancak yedi yılda bir gökyüzünde Batı'dan ve Doğu'dan gelen parlak bir yıldızın etkisiyle pınar taştığında faydalıdır. Alı bu pınarın suyunun faydalarını, kimsenin bilmediği özelliklerini bilir ve oğluna bu sırları anlatır: "Her kim ki Goşabulag'ın suyundan içse âşlk olur. Sesi o kadar güçlü olur ki ormandaki arslanlar ondan ürker, kaplanlar tüylerini döker, kuşlar korku içinde kanat çırpar, dağlar taşlar titrer, atlar ve katırlar pençelerini döker. (Köroğlu 2005: 57) Pınarın suyundan içen Köroğlu'nun narası çok uzaktan duyulur ve sesi düşmanı korkuya düşürürdü.. Yiğidin, pınarın suyundan kuvvet alan narasının gücü Mısri kılıcıyla eşdeğer olarak görülürdü.

Destanın “Demircioğlu'nun Çamlıbel'e Gelişi” kolunda Köroğlu'nun narasının gücünü Demircioğlu şöyle ifade etmiştir: "Kılıcı, kalkanı veya muskasından korkmuyorum. Ama savaşırken kendine has bir narası olduğunu söylüyorlar... Rivayete göre çok yüksek sesle nara atar..”(Köroğlu 2005: 108) Hikayenin anlatımında Köroğlu'nun kükremesini duyan Demircioğlu, bu sesin gücüyle kendinden geçer. "Suları sıçrayarak geçen atlara, yıldırım parçasından (ateşten) kılıçlara ve Goşabulag suyuyla cilalanan bir deli naraya sahip olan Köroğlu'nun gücü bu efsanevi unsurların etkisiyle bire beş artmıştır”. (Eposşinaslık: Problemler, Mülahazalar 2013: 66) Pınarın kaynayan köpüklü suyu da yaşam suyu olarak nitelendirilmiş ve birçok hastalığa iyi geldiği kabul edilmiştir. Rövşen’in içtiği köpüklü su kollarına, sesine ve şiirine güç vermiştir. Böylelikle yenilmez bir pehlivana ve kahramana dönüşmüştür. "İçtiğin köpük senin kollarına güç,sana şairlik verdi. Bir de senin sesine ve narana öyle bir güç gelecek ki İsrafil’in suru onun yanında sinek vızıltısı gibi kalacak”.(Köroğlu 2005: 58) Destanın Paris nüshasının birinci bölümünde Rövşen ve babası Mirza Sarraf hakkında anlatılan hikayede, Goşabulag'ın tanımı içerik bakımından aynı kalmış ve efsanevi dünya görüşünün izlerini korumuştur. (Köroğlu. Paris Nüshası 2005: 13) "Köroğlu" destanının farklı versiyonlarında, Goşabulag'ın tanımı efsanevi unsurları ve dünya görüşünü yansıtmış, kahramanın gizemli bir şekilde güç kazanmasına yardımcı olmuştur.

"Köroğlu" destanında mistik unsurların izlerini aksettiren bir diğer öge yiğidin Mısri kılıcıdır. Destanda Mısri kılıç hakkında birçok detay bulunmaktadır, üstelik onun tasvirindeki canlılık ve mitolojik unsurlar destanın tüm varyantlarında korunmuştur. "Mısri kılıcı güneş, ışık, yıldırım ve ateş ile ilişkili mitik bir doğaya sahiptir ve daha çok antropomorfik Mithr-Misr-Mehr ile ilişkilidir". (Köroğlu. Paris Nüshası 2005: 218) Destandaki Mısri kılıcın hikayesi, kılıcın gücünü ve yenilmezliğini ve aynı zamanda yaratılmasındaki mistik unsurların varlığını ortaya çıkarmıştır. Köroğlu'nun gücüne güç katan, düşmanla savaşlarda onu koruyan ve ona yardım eden asıl vasitalardan biri Mısri kılıcıdır. Yiğit, kılıcıyla kervanlar basmış, düşmanları yenmiş ve kaleleri ele geçirmiştir. Bu kılıç sıradan bir silah değildir, o, elmas gibi parlıar, ay gibi ışık saçar. Rövşen’in babası, demirciden yıldırım parçasından düşen bir taştan kılıç yapmasını istemiştir. Alı, engin tecrübesi sayesinde bu parlayan taşın sıradışılığınından haberdardıve kılıç hazır olduğunda Rövşen'e verererekşöyle demiştir: “Bundan böyle Mısri kılıç diyeceksiniz. Sen Kırat’ın üzerindeyken, kılıç da senin belindeyken hiçbir düşman sana zarar veremez”. (Köroğlu 2005: 54) Destanın başka diğer bir baskısında demirci kılıcını Köroğlu'na verir ve şöyle der: "Bu kılıcın kendisi yıldırımdan, suyu Miskhana suyundan ve ağzının akışı Alkhar gümüşünün ham tozundandır. Buna Mısri kılıç adını verdim.” (Köroğlu 2005: 30)

Destanda Köroğlu, düşmanla savaşan delilerine nişan vermek için Mısri kılıcına bir şiir okuyarak Deli Mehtar'ı haberdar eder : 
"İki serdar bir araya geldiğinde,

Seslenirler orduya gel olur,

Duman keser sür lekenin gözünü,

Mısri kılıç o vakit elde dal olur” (Köroğlu. Paris Nüshası 2005: 171)

Mısri kılıç ifadesi destanda hem Köroğlu'nun delilerinin silahı hem de genel anlamda kullanılmıştır. Destanın "Köle Kaçışı" kolunda (Köroğlu 2005: 233) Alamgulu Han`ın ordusu delilere saldırdığında, Demircioğlu'nun yiğitleri haykırarak söylerler:

"Mısri kilıcı alın ele

Sen o yandan, ben bu yandan! .

Al kanı döndürelim sele

Siz o yandan, ben bu yandan! .. (Köroğlu 2005: 237)

Destanın Paris baskısının son bölümünde Köroğlu, yaşlandığını dile getirir, artık savaşmayacağına ve kılıcını asla kınından çekmeyeceğine dair yemin eder: "Mısri kılıcımı duvara asarak bundan sonra hiçkimseyekılıç çekmeyeceğime dair yemin ettim.” (Köroğlu. Paris Nüshası 2005: 213)

"Köroğlu" destanının mucizevi ve efsanevi içerikle bağlı olarak mitolojik motiflerin ve unsurların varlığı, Goşabulag ve Mısri kılıcın anlatıldığı olaylarda yer almıştır. Destanda, Mısri kılıç kahramanların gücünü artıran bir silah olarak gösterilmiş, Goşabulag'ın suyu Köroğlu'nun bedenine kuvvet, yenilmezlik ve kendisine şairlik vermiştir.

Moğol ve Türk mitolojisinde, kahramanın atı aynı zamanda olağanüstü yönleri ile bilinen, doğaüstü ve büyülü güçlere sahip bir varlıktır. Kalmık halkının asırlar boyunca verdiği tarihi mücadelesinde, at her zaman kahramanın en yakın ve yeri doldurulamaz arkadaşı olmuştur. At sadece kahraman için bir silah arkadaşı değil, aynı zamanda zor durumlarda ona rehberlik eden sadık bir dostudur. Moğol destanındaki bir atın görüntüsünü analiz eden V.Jirmunski, Moğol destanında at imgesini incelerken şöyle yazmıştır: "Türk ve Moğol halklarının kahramanlık masallarında, göçebe yaşam koşullarında sihirli bir yardımcı olarak atın özel bir yeri vardır. Bir at derisini değiştirerek bir yıldıza, bir kuşa veya sineğe dönüşebilir. Halk hikayelerinin estetik kurallarına uygun olarak, silkinerek küçük bir ayğıra `sıska, yaramaz bir kız ' haline dönüşür. O, ölmüş kahramanın yaşam suyuyla dirilir veya kuyruğunun bir bölümünü yetmiş sajens derinliğindeki bir kuyuda sallayarak onu yeraltı karanlığından çekip çıkartır”. (Jirmunski 2017: 27)

"Cangar" destanında her canlının kutsal olduğu Bumba ülkesinde, at da özel anlam taşıyan bir varlıktır. Cangar'ın Aranzalı, Al Aslan Hongor'un Otsola Keke, Altan Tsedji'nin Kula ve diğer kahramanların atları örneğinde bu atlar gerçek dostluğun ve sadakatin sembolüdür. Köroğlu'nun Kırat'ı gibi Cangar'la birlikte savaşlara katılan Aranzal, onu defalarca savaş meydanlarından yaralı haldeyken kurtarmıştır.

"Ön ve arka bacaklarını attığında

İki günlük bir mesafeyi kat ederdi.

Göğsünü öne atarak kaçtı̆̆ı zaman

Kara toprağa dayanan çenesini göğsüyle taşırdı”. (Cangar 2017: 47) 
Aranzal nefesiyle otları ikiye bölerdi. Cangar'ın atı bir insan gibi konuşabilir, sahibine tavsiyelerde bulunabilir, zor durumlarda ona rehberlik ederdi. Bir atın bedenini değiştirerek farklı bir varlığa dönüşmesi, destandaki imgelerin bir kopyası (ikileşmesi) olması ilgi çeken detaylardandır. AlHongor'un atı Otsolo Keke "küçük bir düğün kuşu gibi uçuyor" (Cangar 2017: 58) Hongor'un vahşi atı, onun savaş alanındaki yenilgisini kabul etmeyerek bir insan gibi konuşur:

"Sen yaşadığın on sekiz cesaretli yıl sonunda

Erkek olmaya karar verdin.

Fakat düşmanı uzaktan gördüğünde

Korkak olmaktan korkmuyor musun? ” (Cangar 2017: 56)

Destanın dokuzuncu kolunda, Mingya'nın Türk Hanı'nın atını kaçırmasından bahsedilirken Türk atlarının azametinin övülmesi dikkat çekicidir:

“Türk asilzadeleri böyle bir ata değer verebilirler.

Bir günde birçok ayda gidilebilecek kadar gidebilirler”. (Cangar 2017: 223)

Türk kahramanlı destanlarında mahiyeti itibarıyla yiğitlerin en yakın arkadaşı ve savaş yoldaşlarından biri atları olmuştur. Kahramanın düşmanlarla savaşlarında, at aynı zamanda onu zor durumlardan çıkaran sadık bir savaşçıdır. Kırat ve Durat, Karagöz, Alapaça, Arabat, Sürdat gibi atlar kahramanın savaş alanında birlikte savaştığı sadık yoldaşlarıdır. Destanda Köroğlu'nun delileri ata binmekte ustadırlar. “Ayvaz Han Durat'ın, Şamlı Bey Bozgar'ın, Cinli Mehdi Garasanil'in, Hasan Bey Aşgardor'un, Deli Hasan Haçadil'in, Sırt Yusuf Kohlenşir'in, İsabali Kamarday'ın, Deli Çovdar Altarpenmez’in bir anda eyerin başına kondu. (Köroğlu 2005: 289) "Köroğlu" destanında tasvir edilen Kırat ve Durat, Çamlıbel'in en ünlü atlarındandır. Her iki at da birçok denemeden alnı ak çıkmış ve Kırat'ın şöhreti sadece Çamlıbel'de değil, aynı zamanda komşu ülkelerde de yayılmıştır. Köroğlu seferlerine Kırat'la gider, savaş meydanında Mısri kılıcıyla Kırat onun temel dayanak noktalarıdır. Destanın “Hamza'nın Kaçırılması” kolunda Köroğlu Hamza’nın yüzüne karşı “At yiğidin dayanağıdır” der.

\author{
"Hamza, ata iyi bak, \\ At yiğidin kardeşidir \\ Onu koru ve kolla \\ At yiğidin kardeşidir”. (Köroğlu 2005: 172)
}

Türk kahramanlık destanlarında, büyük önem taşıyan at motifi, aynı zamanda mitolojik unsurlar içeren varlıklar olarak tasvir edilmiştir. Alı, Kırat ve Durat'in fevkalade ve olağanüstü güce sahip atlar olacağını önceden bilir. Durat ve Kırat, nehirden çıkan bir aygırdan doğmuş ve kırk gün boyunca insan yüzü görmeden karanlık bir ahırda beslenmiştir. Kıratın, mitolojik özelliklerinden biri kanatlı olarak tasvir edilmesidir. Destanın Paris nüshasında Alı, Kırat'ın üzerine ışık sızdığını belirterek Kırat’ın uçamayacağını söyler. "Bu 'uçan at' motifi, Türk inançlarında atların göksel kökenli olduğunu göstermektedir". (Çufadar 2019: 220) Ancak Kırat eşi benzeri olmayan yıldırım gibi hızlı bir at olarak yetiştirilmiştir. Kırat aynı zamanda Köroğlu'nun en değerli varlı̆̆ı, onu sıkıntılardan kurtaran sırdaşıdır. Düşmanın yaklaştığını hisseden Kırat yerinde duramaz: "Kırat önce yüksek sesle kişnedi, sonra ayaklarını yere vurdu, şimdiyse ağzından köpükler geliyor ve tırnaklarıyla toprağı kazmaya başladı”. (Köroğlu. Paris Nüshası 2005: 77) Köroğlu, Kırat’ın bu işaretlerini görünce düşmanın

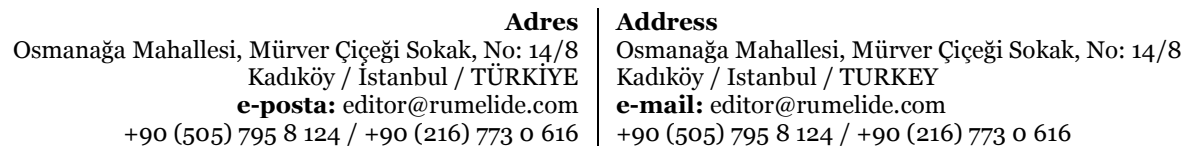


yaklaşmakta olduğunu anladı ve tedbirini aldı. Destanda Köroğlu, Kırat'ın değerinin ölçülemeyeceğini Hamza'ya şöyle anlatıyor:

\author{
"Sana Kırat'ın kıymetini söyleyeyim, \\ Seksen bin savaş̧̧, mala da verme! \\ Seksen bin beyaz saçlı mehtaba, \\ Seksen bin hazine pula da verme! ” (Köroğlu 2005: 171)
}

Destanda Kırat, kahramanın en yakın yardımcısı, ona karşı sadakatli mücadele arkadaşıdır. Köroğlu, tüm güç ve kuvvetini Kırat’tan almıştır. Destanda Kırat, olağandışllığı ve efsanevi doğaüstü gücü nedeniyle diğer atlardan farklı bir şekilde betimlenmiştir. Moğol destanı ve "Köroğlu" destanında, atlar mitolojik ve olağanüstü güçlere sahip bir varlık olarak karşımıza çıkar.

\title{
4. Sonuç
}

Moğol destanları arasında kendine has bir yeri olan "Cangar", Kalmık halkının yurtseverliğinin ve mücadelesinin en değerli örneklerinden biridir. "Cangar" destanının analizi Kalmık halkının tarihsel geçmişini, geleneklerini, gündelik yaşamlarını ve sosyal yaşama ait tasavvurlarını incelemek için çok zengin bir kaynaktır. Anavatanlarının bütünlüğü, özgürlüğü ve refah içinde yaşamak Bumba halkının vazgeçilmez arzusudur. Kahramanların, özellikle Cangar'ın tek hedefi, Bumba ülkesinin ebedi ve sarsılmaz bağımsızlığını korumaktır. Destanın kahramanlarının düşmana karşı ebedi mücadelesinin asıl gayesi bu düşüncedir. Al Hongor ve Altan Tsedji, bu amaçla savaşan kahramanlara liderlik eden savaşçlardır.

"Köroğlu” destanında halk kahramanı Köroğlu ve 7777 delisi hak ve adalet için savaş verir. Köroğlu ve delilerinin tarihi kimliği destanda birçok karakterin isimlerinin gerçek olmasılyla da kendisini gösterir. Mücadele ve cesaret motifleri taşıyan "Köroğlu" destanında Moğol destanında olduğu gibi mitik unsurlar yer almaktadır.

"Cangar" ve "Köroğlu" destanlarında kahramanların düşmanlarla mücadelesi anlatı boyunca kahramanların tek başlarına ve ortak mücadelesi şeklinde tanımlanır. Bu mücadele destanın ana kahramanı ve onun yiğitlerinin farklı amaçlar uğrunda verdiği savaşlardır. Tarihle örtüşecek şekilde anlatılan olaylarda kahramanlık, mertlik ve yiğitlik motifleri görülmektedir.

Moğol ve Türk destanlarında halk edebiyatının ana unsurlarından biri olan mitler de yer alır.. "Cangar" destanında bu unsurlar sihirli varlıklar olarak tasvir edilmiş ve kahramanların mitolojik güçlerle mücadelesinde de kendisini göstermiştir. Efsanevi unsurları yansıtan "Köroğlu” destanının “Alı Kişi” kolu, mitolojik bir dünya görüşünün izlerini taşımaktadır.

Kahramanlık destanlarının tüm özelliklerini yansıtan Moğol ve Türk destanları tema ve içerik, fikirler, imgelerin özellikleri, günlük yaşamın tasviri ve motifleri bakımından ortak özellikler içermektedir.

\section{Kaynakça}

- (2004). İskendername. Bakü: Lider Neşriyat”.

-. (2005) Köroğlu. Bakü. Şark Garp.

-. (2005). Köroğlu. Bakü: Lider Neşriyyatı.

-. (2016). Altay Destanları ve Efsaneleri. Bakü: İlim ve İrfan.

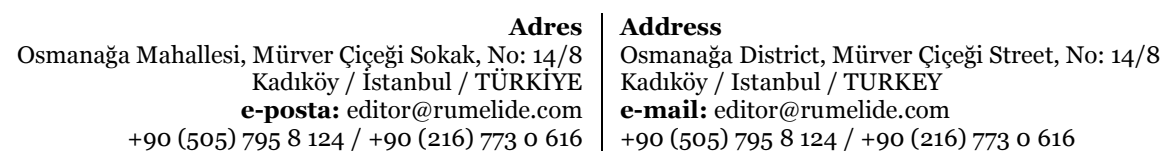


Alekseyeva, P. E.; Bitkiyeva, N.Ç. (2001). “Cangar” ve Cangarşinaslık: Bibliyografi. Elista Yayınevi.

Alibeyzade E. (2005). Avesta Azərbaycan Halkının Manevi Kültür Tarihidir. Bakü: Yurt.

Azizhan T. (2015). Köroğlu'nun Şiir Dili. Bakü: İlim ve İrfan.

Banarlı, Nihat Sami (1998). Resimli Türk Edebiyatı Tarihi, İstanbul: Milli Egitim Basımevi.

Bayat, Fuzuli (2009). Türk Destancılık Bağlamında Köroğlu Destanı. İstanbul: Ötüken.

Bergmann, Benjamin (1804). Nomadischeunter den Kalmüken. Riga.

Beydili, Celal (2007). Türk Mifolojik Kahramanlar Sistemi: Yapı ve Fonksyon (Monografi). Bakü: Mütercim.

Buyar, Cengiz (2016). “Geçmişten Günümüze Cangar Destanı”. Notlar. Milli Folklor, yll 28, sayı 109, s. $113-127$

Caferli, M. (2007). Destan Yaratıcılığı. Bakü: İlim.

Caferov, N. (1998). Türk Dünyası: Kaos ve Kosmos. Makaleler Toplusu. Bakü: Azerbaycan Üniversitesi.

Çelebi Evliya (2010). Seyahatnâmesi, 5. Kitap 1. Cilt. İstanbul: Yapı Kredi.

Çufadar, N. (2019). "Köroğlu Destanı'nda Atın Mitolojik Göstergeleri”. RumeliDE Dil ve Edebiyat Araştırmaları Dergisi, Ö5, Ağustos, s. 215-226

Gasımovai F.; Osmanova G. (2013). Eposşinaslık: Problemler, Mülahazalar. Gasımova F., Osmanova G., Bakü: İlim ve İrfan.

Gurbanovi B. (2017). Cangar. Bakü: Şur.

Gurbanovi B. (2017). Önsöz Yazarı. "Kalmık Halsının Kahramanlık Destanı Cangar `da Türk Kökenli Unsurlar”, Kredo, 16 Ağustos, s. 2-16.

He Dexiu (2017). Cangar: Moğolların Büyük Destanı. İstanbul: İpekyolu.

Jirmunski, V. (2017). Halk Kahramanlık Eposu. Bakü: Azerbaycan Çeviri Merkezi.

Meletinski E. M. (1963). Kahramanlık Destanının Menşei, İlk Hali ve Arkaik Meseleler. Moskova. 